Jurnal Spektrum Komunikasi Vol 6 No. 2 Desember, 2018

\title{
KODE ETIK JURNALISTIK: PEMBERITAAN PILGUB JATIM DI HARIAN JAWA POS EDISI 1-28 FEBRUARI 2018
}

\author{
JOURNALISTIC CODE OF ETHICS: EAST JAVA GOVERNOR \\ ELECTION NEWS IN JAWA POS (1-28 FEBRUARY 2018)
}

\author{
Rohmat Darmawan \\ Dinas Perhubungan Pemerintah Kota Surabaya \\ Email : rohmatdarmawan.sby@gmail.com
}

\begin{abstract}
This study focuses on "Application of the Journalistic Code of Ethics to the Preaching of the East Java Pilgub in Jawa Pos Daily Edition 1- 28 February 2018." This research was conducted with the aim of describing the application of the Journalistic Code of Ethics in Jawa Pos daily. As well as to determine the suitability of the East Java election in the Jawa Pos daily with a journalistic code of ethics which has been attached to the Press Council Decree No. 03 / SK-DP / III / 2006. Every news that is aired should be neutral and balanced. Moreover in East Java during the gubernatorial election there were two candidate pairs. This study uses the content analysis method. There are three concepts included in content analysis. First, this analysis is systematic. This means that the content to be analyzed is chosen according to implicitly defined rules, for example; how to determine the sample. Second, content analysis is objective. Third, content analysis is quantitative. There are five objectives of content analysis, namely; (Eriyanto, 2011: 32-42) First, describe the characteristics of the message. Second, describe in detail the content. Third, see messages to different audiences. Fourth, look at messages from different communicators. Fifth, drawing conclusions from the contents of a content analysis message is never used as a basis for making statements about the effect of content on the audience. The researcher also analyzed each element of text produced by the news writer. At the news of the East Java Governor Election in Jawa Pos daily, it was sometimes included in the Politika rubric. Depends on the scale of news influence at that time. If it affects the people of Indonesia, then it will be contained in the national political rubric.After being analyzed, the coverage of the jatim pilgub in Jawa Pos daily was found both in the Politika rubric and the main page, there were a number of editions violating the Journalistic Code of Ethics, especially articles 1,2 and 8. Jawa Pos made the East Java Election Report as a media for public education in political contestation in East Java. So it is required to be neutral and in accordance with the rules of journalistic ethics prescribed by the press council. Article 1 Indonesian journalists are independent, produce news that is accurate, balanced and not in bad faith
\end{abstract}

Keywords: Election of East Java Governor, Jawa Pos, Journalistic Code of Ethics, Press Council

\section{ABSTRAK}

ISSN 2338 - 0861 (cetak); e-ISSN 2621 - 8712 (online)

website : http://spektrum.stikosa-aws.ac.id 
Penelitian ini berfokus pada "Penerapan Kode Etik Jurnalistik pada Pemberitaan Pilgub Jatim di Harian Jawa Pos Edisi 1- 28 Februari 2018." Penelitian ini dilakukan dengan tujuan mendeskripsikan penerapan Kode Etik Jurnalistik di harian Jawa Pos. Serta untuk mengetahui kesesuaian pemberitaan pilgub Jatim di harian Jawa Pos dengan kode etik jurnalistik yang sudah terlampir dalam SK Dewan Pers No. 03/SKDP/III/2006. Setiap berita yang ditayangkan sudah seharusnya netral dan berimbang. Terlebih lagi di Jatim saat pemilihan gubernur ada dua pasangan calon. Penelitian ini menggunakan metode analisis isi. Ada tiga konsep yang tercakup di dalam analisis isi. Pertama, analisis ini bersifat sistematis. Hal ini berarti isi yang akan dianalisis dipilih menurut aturan-aturan yang ditetapkan secara implisit, misalnya; cara penentuan sampel. Kedua, analisis isi bersifat obyektif. Ketiga, analisis isi bersifat kuantitatif. Ada lima tujuan analisis isi, yaitu; (Eriyanto,2011 : 32-42) Pertama, menggambarkan karakteristik dari pesan. Kedua, menggambarkan secara detail isi (content). Ketiga, melihat pesan pada khalayak yang berbeda. Keempat, melihat pesan dari komunikator yang berbeda. Kelima, menarik kesimpulan penyebab dari suatu pesan analisis isi tak pernah dijadikan dasar untuk membuat pernyataan tentang efek isi kepada audience. Peneliti juga menganalisis setiap elemen teks yang diproduksi penulis berita. Pada pemberitaan Pilgub Jatim di harian Jawa Pos, terkadang dimasukkan ke dalam rubrik Politika. Tergantung dari skala keterpengaruhan berita saat itu. Jika berdampak pada masyarakat se Indonesia maka dimuat dalam rubrik politika nasional.Setelah di analisa, pemberitaan pilgub jatim di harian Jawa Pos ditemukan baik pada rubrik Politika maupun halaman utama ada sejumlah edisi melanggar Kode Etik Jurnalistik, khususnya pasal 1,2 dan 8. Jawa Pos menjadikan Pemberitaan Pilgub Jatim sebagai media edukasi masyarakat dalam kontestasi politik di Jawa Timur. Sehingga diharuskan untuk bisa netral dan sesuai dengan perturan kode etik jurnalistik yang ditentukan dewan pers. Pasal 1 Wartawan Indonesia bersikap independen, menghasilkan berita yang akurat, berimbang, dan tidak beritikad buruk.

Kata-kata Kunci: Pilkada, Pilgub Jatim, Jawa Pos, Kode Etik Jurnalistik, Dewan Pers

\section{PENDAHULUAN}

Sejak diberlakukannya UndangUndang Pers (Undang-Undang Nomor 40 Tahun 1999) di era pemerintahan Presiden BJ Habibie, pers Indonesia mendapat kemerdekaan (baca: kebebasan). Muncul istilah pers Indonesia, "sekali merdeka, merdeka sekali". Sebab, di era sebelumnya pers Indonesia telah dibelenggu oleh rezim Orba (Orde Baru). Namun, kebebasan pers di era reformasi dewasa ini harus berlandaskan kepada "kebebasan yang bertanggung jawab".

Dengan dibukanya kran kebebasan pers, maka banyak bermunculan media di kota-kota besar hingga daerah-daerah, bagai jamur yang tumbuh di musim hujan. Praktis, untuk mendirikan media sudah tidak lagi dibutuhkan pengurusan SIUPP (Surat Izin Usaha Penerbitan Pers), yang dulu dikeluarkan oleh Departemen Penerangan di era pemerintahan Presiden Soeharto. Cukup mempunyai lembaga berbadan hukum PT, CV, atau yayasan.

Sayang, dengan berdirinya banyak media tidak diimbangi dengan standar perusahaan pers, standar kompetensi wartawan, standar penggajian wartawan, standar mekanisme (prosedur) jurnalistik, standar etika (kode etik) jurnalistik,

ISSN 2338 - 0861 (cetak); e-ISSN 2621 - 8712 (online)

website : http://spektrum.stikosa-aws.ac.id 
dan sebagainya. Eksesnya (dampak negatif) terjadi banyak pelanggaranpelanggaran Kode Etik Jurnalistik yang dilakukan oleh media dan wartawannya. Telah terjadi salah tafsir tentang kebebasan pers menjadi "kebebasan yang kebablasan".

Pewarta media/jurnalis/wartawan dalam melaksanakan tugasnya didasari atas nilai-nilai etis profesi. Di antaranya: (1) Kesadaran (awareness), mencakup kesadaran tentang etika dan hukum. Dituntut menyadari norma-norma etika dan ketentuan hukum; (2) Memiliki integritas, tegas dalam prinsip, dan kuat dalam nilai. Dalam melaksanakan misinya wartawan harus beretika, memiliki tekad untuk berpegang pada standar jurnalistik yang tinggi, dan memiliki tanggung jawab; (3) Wartawan harus terus meningkatkan kompetensi etikanya, karena wartawan akan lebih siap dalam menghadapi situasi yang pelik; (4) Untuk meningkatkan kompetensi etika, wartawan perlu mendalami Kode Etik Jurnalistik dan kode etik organisasi wartawan masing-masing; (5) Sebagai pelengkap pemahaman etika, wartawan dituntut untuk memahami dan sadar ketentuan hukum yang terkait dengan kerja jurnalistik; (6) Wartawan wajib menyerap dan memahami UndangUndang Pers, menjaga kehormatan, dan melindungi hak-haknya; (7) Salah satu kompetensi kunci wartawan adalah memahami dan mentaati etika jurnalistik.

Kewajiban tentang Kode Etik Jurnalistik ini diatur dalam UU Pokok Pers dan KEWI (Kode Etik Wartawan Indonesia). Menurut UU No. 40/1999 tentang Pers, Kode Etik Jurnalistik adalah himpunan etika profesi wartawan. Pasal 7 ayat (2) UU No. 40/1999 tentang Pers menyatakan "Wartawan memiliki dan menaati
Kode Etik Jurnalistik". Dalam penjelasan disebutkan, yang dimaksud dengan Kode Etik Jurnalistik adalah Kode Etik yang disepakati organisasi wartawan dan ditetapkan oleh Dewan Pers.

Berdasarkan data pengaduan di Dewan Pers pada tahun 2012, sebanyak $70 \%$ dari kasus yang ditangani/dimediasi berakhir dengan keputusan bahwa terjadi pelanggaran kode etik jurnalistik oleh media atau jurnalis. Menurut AJI (Aliansi Jurnalis Indonesia), $60 \%$ media melanggar kode etik. PWI (Persatuan Wartawan Indonesia) menyarankan untuk menegakkan Kode Etik Jurnalistik dengan UKW (Uji Kompetensi Wartawan).

Jenis-jenis pelanggaran kode etik jurnalistik itu di antaranya: tanpa akurasi/tidak disiplin verifikasi, bukan kepentingan publik, kepentingan politik, hanya untuk kepentingan ekonomi, hanya untuk kepentingan kekuasaan, tujuan pemerasan, niat-itikad buruk, tidak berimbang, tidak menampilkan keutuhan berita (sepotong-potong), tidak menampilkan $5 \mathrm{~W}+1 \mathrm{H}$, trial by the press (menghakimi/memvonis), tidak menghormati privasi narasumber, tidak menghormati off the record, melanggar confidential sources (sumber-sumber yang tidak mau disebut namanya), SARA (Suku, Agama, Ras, Antargolongan), tidak sembunyikan identitas korban kejahatan asusila, penghapusan berita tanpa penjelasan, plagiat/plagiarisme/penjiplakkan, tidak menyebutkan narasumber, tidak menyebutkan sumber informasi, tidak independen/tidak objektif/memihak, menampilkan konten pornografi/cabul, menampilkan konten sadism, sengaja merusak reputasi seseorang (pembunuhan karakter), memuat informasi bohong ISSN 2338 - 0861 (cetak); e-ISSN 2621 - 8712 (online)

website : http://spektrum.stikosa-aws.ac.id 
(kebohongan publik), memuat berita fitnah (prasangka tanpa dasar), merendahkan martabat orang lemah, miskin, cacat, dsb, menebarkan kebencian dan provokatif, menyalahgunakan profesi jurnalis/wartawan, menerima suap, terlalu bombastis/sensasional, tanpa dukungan fakta, mencampuradukkan fakta dan opini.

Ketika sebuah produk atau hasil karya jurnalistik memihak pada seseorang, maka salah satu ada yang merasa dirugikan. Sehingga, seseorang yang merasa dirugikan atau disudutkan merasa tidak nyaman. Maka, sangat mudah sekali mengajukan tuntutan kepada penulis berita tersebut. Jika pemberitaan dianggap merugikan, akan diadukan ke Dewan Pers. Namun, ada kalanya diawali dengan melayangkan somasi kepada media yang bersangkutan. Dewan Pers pun akan memberikan keputusannya. Di antaranya penanggung jawab/pemimpin redaksi media tersebut harus memberikan hak jawab, koreksi, atau ralat (pembetulan).

Lebih khusus disebutkan dalam Pasal 5 Undang-Undang Pokok Pers. (1) Pers nasional berkewajiban memberitakan peristiwa dan opini dengan menghormati norma-norma agama dan rasa kesusilaan masyarakat serta asas praduga tak bersalah. (2) Pers wajib melayani Hak Jawab. (3) Pers wajib melayani Hak Koreksi.

Dalam perkembangannya terjadi perubahan paradigma tentang kredibilitas pers. Jika dulu orang berpendapat bahwa pers yang kredibel adalah pers yang tidak pernah membuat kesalahan. Kini, pers yang kredibel adalah pers yang juga berani mengakui kesalahannya. Juga, berani minta maaf kalau benar-benar melakukan kesalahan. Mulai jajaran pemimpin redaksi/penanggung jawab, wapimred, redaktur pelaksana, koordinator liputan, redaktur, dan reporter wajib menaati kode etik jurnalistik tersebut.

Semua wartawan di jajarannya masing-masing harus memahami mekanisme (prosedur) karya jurnalistik sebagai berikut: (1) How to get a news (bagaimana mencari berita)? Apakah cara mendapatkan berita sudah benar? Perencanaan berita dan organisasi peliputan mesti dilakukan secara serius. (2) How to write a news (bagaimana menulis berita)? Apakah penulisannya sudah baik? Pimred/Wapimred, Redpel, Korlip, dan Redaktur harus bisa "menulari" menulis yang baik dan benar. (3) How to present a news (bagaimana menyajikan berita)? Apakah penyajiannya sudah menarik? Lay-outnya, fotonya, ilustrasinya, sudahkah sesuai selera pembaca?

Seluruh jajaran redaksi (Pimred/Wapimred, Redpel, Korlip, Redaktur, Reporter) harus memahami dan melaksanakan deskripsi tugas/kewajiban masing-masing. Untuk dapat mewujudkan peliputan yang baik dan benar harus ditunjang dengan organisasi yang rapi. Sementara ini, terdapat beberapa pola manajemen redaksi. Jumlah dan bidangnya bisa fleksibel, disesuaikan kebutuhan.

Berdasarkan pemaparan di atas, maka dapat dikemukakan rumusan-rumusan masalah penelitian yaitu Bagaimana penerapan Kode Etik Jurnalistik pada pemberitaan Pilgub Jatim di Harian Jawa Pos edisi tanggal 1 hingga 28 Februari 2018? Penelitian ini dilakukan dengan tujuan mendeskripsikan penerapan Kode Etik Jurnalistik di Harian Jawa Pos. Serta untuk mengetahui kesesuaian pemberitaan Pilgub Jatim di Harian Jawa Pos dengan kode etik 
jurnalistik yang sudah dibuat oleh Dewan Pers.

\section{METODOLOGI}

Dalam penelitian ini menggunakan metode analisis isi, ada tiga konsep yang tercakup di dalam analisis isi. Pertama, analisis ini bersifat sistematis. Hal ini berarti isi yang akan dianalisis dipilih menurut aturan-aturan yang ditetapkan secara implisit, misalnya; cara penentuan sampel. Kedua, analisis isi bersifat obyektif. Ketiga, analisis isi bersifat kuantitatif. Ada lima tujuan analisis isi, yaitu; (Eriyanto,2011 : 32-42) Pertama, menggambarkan karakteristik dari pesan. Kedua, menggambarkan secara detail isi (content). Ketiga, melihat pesan pada khalayak yang berbeda. Keempat, melihat pesan dari komunikator yang berbeda. Kelima, menarik kesimpulan penyebab dari suatu pesan analisis isi tak pernah dijadikan dasar untuk membuat pernyataan tentang efek isi kepada khalayak.

$$
\text { Temuan-temuan dalam }
$$

analisis isi tertentu dibatasi oleh kerangka kategori-kategori dan definisi yang digunakan dalam analisis isi adalah kurangnya pesanpesan yang relevan dengan penelitian tersebut. Analisis ini juga digunakan untuk menggambarkan kecenderungan dari suatu pesan komunikasi. Prosedur dari analisis isi adalah dengan jalan mengukur atau menghitung aspek dari isi (content) dan menyajikan secara kuantitatif. Analisis isi kuantitatif harus dapat dibedakan dengan jenis-jenis analisis lainnya, seperti semiotika, framing, wacana, naratif, dan banyak lagi. Secara umum analisis isi kuantitatif dapat didefinisikan sebagai suatu teknik penelitian ilmiah yang ditujukan untuk mengidentifikasi secara sistematis isi komunikasi yang tampak (manifest), dan dilakukan secara valid, reliabel, dan dapat direplikasi. Barelson (1952:18) menyatakan analisis isi sebagai suatu teknik penelitian yang dilakukan secara objektif, sistematis, dan deskripsi kuantitatif dari isi komunikasi yang tampak (manifest). Krippendorff (1980: 21; 2006: 8) menyatakan analisis isi adalah suatu teknik penelitian untuk membuat inferensi yang dapat direplikasi (ditiru) dan sahih datanya dengan memerhatikan konteksnya

\section{HASIL DAN PEMBAHASAN}

Pada pemberitaan Pilgub Jatim di Harian Jawa Pos, memuat sejumlah berita hard news tentang perkembangan dunia politik khususnya di Jawa Timur. Isu politik di jatim yang berpengaruh terhadap masyarakat luas berskala nasional bisa juga dimuat dalam halaman utama atau head line. Namun apabila berita tersebut hanya berpengaruh dalam skala regional atau hanya seJatim, hanya dimuat dalam halaman rubrik Jawa Timur. Tergantung dari peristiwa yang terjadi saat itu. Selain itu, terkadang berita Pilgub Jatim juga terpampang di halaman Politika.

Pemberitaan Pilgub Jatim yang dimaksud fokus pada edisi bulan Februari. Segala informasi tentang tahapan proses pemilihan Gubernur Jatim. Di antaranya ketika penetapan calon, hingga dimulainya masa kampanye tersebut dilaksanakan pada bulan Februari.

Dalam hal ini, peneliti memilih beberapa edisi yang terdapat sejumlah pelanggaran. Yakni sebagai berikut:

- $\quad$ Kamis, 1 Februari 2018

- $\quad$ Rabu, 7 Februari 2018

- Sabtu, 10 Februari 2018 
- $\quad$ Senin, 12 Februari 2018

- Kamis, 15 Februari 2018

- Jum'at, 16 Februari 2018

- Rabu, 21Februari 2018

- Kamis, 22 Februari 201

- Sabtu, dan Sabtu, 24 Februari 2018

\section{Penyajian Data}

Dalam penelitian ini, peneliti menganalisis isi yang dipilih menurut aturan-aturan yang ditetapkan secara implisit, misalnya; cara penentuan sampelnya. Analisanya bersifat objektif. Ada lima tujuan di dalam penelitian menggunakan analisis isi, yaitu; (Eriyanto,2011 : 32-42) Pertama, menggambarkan karakteristik dari pesan. Maka peneliti memfokuskan pada pemberitaan Pilgub Jatim di Harian Jawa Pos edisi Februari 2018. Kedua, menggambarkan secara detail isi (content). Melakukan penelitian pada setiap detail kalimat pada naskah berita. Ketiga, melihat pesan pada khalayak yang berbeda. Keempat, melihat pesan dari komunikator yang berbeda. Kelima, menarik kesimpulan penyebab dari suatu pesan analisis isi tak pernah dijadikan dasar untuk membuat pernyataan tentang efek isi kepada audience.

Peneliti menghubungkan analisis isi dengan undang-undang kode etik jurnalistik. Penelitian terhadap teks ini meliputi tema/topik yang ditulis, pemilihan kata, hingga penekanan makna. Setelah dilakukan analisis terhadap keseluruhan data dan teks, maka selanjutnya peneliti menentukan edisi mana yang terdapat banyak melakukan pelanggaran (reduksi data). Teknik reduksi data berkaitan dengan studi deskriptif ini, yaitu melihat tingkat pelanggaran yang terdapat pada pemberitaan Pilgub Jatim. Tahap selanjutnya adalah dilakukan wawancara kepada tiga orang. Pemimpin redaksi harian Jawa Pos Marsudi Nurwahid, Redaktur berita politik Firzan Syahroni, dan Wartawan pemberitaan pilgub jatim Aris Imam.

\section{Analisis Iis}

Berita Pilgub jatim termasuk ke dalam Straight News, yaitu jenis berita yang disampaikan secara langsung, teraktual, hangat dan menarik. Berita Pilgub Jatim ini menginformasikan dan memberitakan mengenai perkembangan politik di Jawa Timur yang sedang memasuki pesta demokrasi. Diberitakan bahwa dua kandidat calon Gubernur Jatim yaitu pasangan Kofifah-Emil dan Saifullah-Puti selama masa kampanye nya, baik itu kegiatan konsolidasi nya dengan tim pemenangan maupun kegiatan-kegiatan sosial kedua pasangan calon.

Dalam proses pembuatan teks berita, wartawan melakukan wawancara secara mendalam guna menggali informasi yang aktual dengan pihak terkait (pasangan calon, aparatur negara, maupun tim sukses kedua paslon). Hal ini dilakukan oleh penulis guna menghindari adanya berita palsu (hoax), kampanye hitam (black campaigne), maupun aktifitas yang bersifat menjatuhkan kedua kandidat.

Ditinjau dari analisis isi, tema dan topik yang dikedepankan fokus pada Pilgub Jatim 2018. Pada bulan Februari terdapat sebanyak sembilan edisi atau sembilan hari yang memuat berita tidak berimbang. Selain itu, pemakaian kalimat, hingga gaya tertentu bukanlah semata-mata dipandang sebagai cara berkomunikasi, akan tetapi sebagai politik berkomunikasi.

Dalam bagian struktur berita, ditemukan kalimat yang sangat jelas

ISSN 2338 - 0861 (cetak); e-ISSN 2621 - 8712 (online)

website : http://spektrum.stikosa-aws.ac.id 
sekali menonjolkan salah satu pasangan calon atau paslon. Seperti memberikan detail yang tidak berimbang dalam beberapa judul dan pemuatan foto. Sehingga memunculkan potensi untuk dapat mempengaruhi pikiran pembaca. Maka, framing pemberitaannya akan dapat dengan mudah membuat pembaca tergiur dan semakin tertarik dengan pasangan Khofifah-Emil. Karena diberitakan lebih bagus daripada pasangan Gus Ipul- Puti. Hal yang tidak berimbang seperti inilah yang seharusnya tidak boleh dilakukan oleh semua media. Karena sesuai dengan Undang-undang yang telah dibuat Dewan Pers sangat jelas tertera di Pasal 1 Wartawan Indonesia bersikap independen, menghasilkan berita yang akurat, berimbang, dan tidak beritikad buruk.

\section{Triangulasi Data - Validasi}

Wartawan Jawa Pos selaku

stake holder dalam pemberitaan Pilgub Jatim menerangkan bahwa salah satu fungsi lembaga pers adalah media penyaji informasi bagi masyarakat. Dalam kontestasi politik yang sedang diadakan di Jawa Timur, yaitu Pilgub Jatim, Jawa Pos mengambil posisi sebagai media edukasi dan informasi bagi masyarakat. Setiap berita yang ditulis berkenaan dengan Pilgub Jatim diharuskan menghindari unsur black campaigne (kampanye hitam), hoax (berita palsu), aktivitas yang bersifat saling menjatuhkan antar kandidat, dan sejumlah unsur lain. Dalam setiap pemberitaan terkait Pilgub Jatim, salah satu dasar yang di gunakan adalah fakta/peristiwa/data. Misal melakukan pengujian data pemilih kepada. Sebagai wartawan yang professional, maka wartawan Jawa Pos menjaga netralitas dan independensi. Jika diperlukan adanya hak jawab dan hak koreksi, maka wartawan siap memberikan jika ditemui adanya kesalahan penulisan, materi, maupun berita yang belum terkonfirmasi kebenarannya.

Integritas dan kejujuran adalah modal awal yang harus dimiliki oleh setiap wartawan. Dalam hal pemberitaan Pilgub Jatim ini, Redaktur berperan penting mengolah sumber informasi yang didapat oleh wartawan. Beberapa tugasnya adalah memberikan judul, memperbaiki redaksi dan menyunting kata. Redaktur Jawa Pos mengungkapkan bahwa dalam hal pengambilan foto sekalipun harus pada angle yang sama antar kedua paslon dalam pemberitaan Pilgub Jatim. Hal paling penting menurut Redaktur adalah memegang asas praduga tak bersalah, menjaga keberimbangan serta selalu mengkonfirmasi setiap informasi yang didapat. Jika dikemudian hari ditemui ada kekeliruan, maka Redaktur siap memberikan hak jawab dan hak koreksi dengan melalui tahap klarifikasi.

Dalam pemberitaan Pilgub jatim, Pimpinan Redaksi mengaku netral dan tidak ada kepentingan apaapa. Berita yang dimuat dihasilkan dari wawancara, mendatangi acara, temuan data di lapangan. Data itu kemudian dimintakan komentar atau konfirmasi pada yang bersangkutan atau juga pendapat orang yang kompeten. Pimpinan Redaksi mengatakan, jika wartawannya terbukti ada yang menerima suap, maka langsung dipecat tanpa melalui proses hukum. Guna menanggulangi adanya kesalahan penulisan dan ketidakberimbangan, Pimpinan Redaksi melakukan rapat evaluasi kepada semua redaktur atas pemberitaan setiap hari. Jika kemungkinan didapati kesalahan, maka Pimpinan Redaksi siap ISSN 2338 - 0861 (cetak); e-ISSN 2621 - 8712 (online)

website : http://spektrum.stikosa-aws.ac.id 
memberikan hak jawab dan hak koreksi. Koreksi akan dilakukan dengan mencantumkan kolom koreksi pada halaman yang sama di edisi berikutnya.

\section{KESIMPULAN}

Pemberitaan Pilgub Jatim, baik pada rubrik Politika maupun halaman utama banyak melanggar Kode Etik Jurnalistik, khususnya pasal 1 Wartawan Indonesia bersikap independen, menghasilkan berita yang akurat, berimbang, dan tidak beritikad buruk. Pasal 2 Wartawan Indonesia menempuh cara-cara yang profesional dalam melaksanakan tugas jurnalistik, dan Pasal 8 Wartawan Indonesia tidak menulis atau menyiarkan berita berdasarkan prasangka atau diskriminasi terhadap seseorang atas dasar perbedaan suku, ras, warna kulit, agama, jenis kelamin, dan bahasa serta tidak merendahkan martabat orang lemah, miskin, sakit, cacat jiwa atau cacat jasmani.

Pemberitaan yang dilakukan oleh wartawan Jawa Pos cenderung mengarah kepada salah satu pasangan calon, yaitu Kofifah-Emil. Rata-rata isi berita berpihak dengan salah satu pasangan calon seperti missal nya hanya melakukan wawancara kepada salah seorang paslon saja padahal di tempat yang sama, dua paslon melakukan kegiatan yang sama pula. Penempatan foto yang kurang berimbang antar kedua pasangan calon. Dari segi ukuran, posisi penempatan, hingga frekuensi.

\section{DAFTAR PUSTAKA}

Charles R. Wright, Severin. 2001. Mass Communication Theories 5th. New York : Mc. Graw Hill

Darma, Yoce A. 2009. Analisis Wacana Kritis. Bandung: Yrama Widya.
Dewan Pers. 2006. Kode Etik Jurnalis Indonesia. Jakarta: Dewan Pers

Eriyanto. 2002. Analisis Framing, Konstruksi, Ideologi, dan Politik Media. Yogyakarta: LKiS.

Kuswarno, Engkus. 2013. Metodologi Penelitian Komunikasi Fenomenologi, Konsepsi Pedoman dan Contoh Penelitian. Bandung: Widya Pajajaran.

Mulyana, Deddy. 2008 . Ilmu Komunikasi Suatu Pengantar. Bandung: Remaja Rosdakarya.

Moerdijati, Sri. 2012. Buku Ajar Pengantar Ilmu Komunikasi. Surabaya: Revka Petra Media

Rakhmat, Djalaludin. 2007. Metode Penelitian Komunikasi. Bandung : Remaja Rosdakarya.

Rusadi, Udi. 2015. Buku kajian media Isu Ideologis dalam Perspektif, Teori, dan Metode . Jakarta: Raja Grafindo Persada.

Sobur, Alex. 2013 . Filsafat Komunikasi Tradisi dan Komunikasi Fenomenologi. Bandung: Remaja Rosdakarya.

Sugiyono. 2012. Metodologi Penelitian Pendidikan. Bandung : Alfabeta

Sugiyono. 2006. Metode Penelitian Kuantitatif, Kualitatif dan R\&D. Bandung : Alfabeta.

Van Dijk, T.A. 1988. News as Discourse. Hillsdale: Lawrence Erlabaum Associates.

Van Dijk, T.A. (Eds.). 1997. Discourse as Structure and Process: Discourse Studies, a Multidisciplinary Introduction. London: Sage Publications.

SURAT KABAR

Jawa Pos edisi 1 - 28 Pebruari 2018 